\title{
Pacific Bananas: Complex Origins, Multiple Dispersals?
}

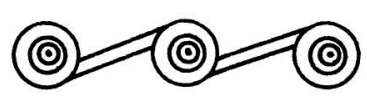

\author{
JEAN KENNEDY
}

BANANAs, all of which belong to genus Musa in the family Musaceae, have been accepted as part of the pre-European suite of Oceanic cultivated plants since the first published descriptions of Pacific peoples (Barrau 1962, 1965; Merrill 1954; Yen 1991). Although they are among the most thoroughly investigated of Oceanic staple food plants (Yen 1973:69-70), the classification and nomenclature of Pacific cultivated bananas continue to be confused and confusing, even though the characteristics that distinguish them from bananas elsewhere were explained in the classic studies of Simmonds $(1959,1962)$. Now that biomolecular analyses are revising the phylogeny of bananas, and their prehistory is beginning to be investigated directly by archaeobotanical analyses, Pacific bananas warrant review.

Two groups of cultivated bananas have long been distinguished in the Pacific, each belonging to a separate section of genus Musa. The Fe'i bananas probably originated in the New Guinea area. Formerly important in Tahiti but generally rare, they are not found outside the Pacific. The other Pacific cultivars belong in a second section of the genus, along with all other cultivated bananas including the common commercial ones. It was believed until recently that cultivars belonging to this more widespread section were introduced to the New Guinea region from the west. Biomolecular evidence has now established that Pacific cultivars of this section form a genetically distinctive group, also with New Guinea parentage (Carreel et al. 1994, 2002; Kennedy in press; Lebot 1999; Lebot et al. 1993, 1994). This group is now known as the Pacific plantains.

Although Pacific domesticated bananas are notable for their imputed antiquity as well as distinctiveness, they have only recently begun to be investigated archaeologically. In Polynesia, there are leaf fragments from Tangatatau rockshelter, Mangaia, Cook Islands (Kirch et al. 1995), and Henderson Island (Weisler 1997), and probable phytoliths from Easter Island (Cummings 1998). These remains are identified only as genus Musa. In the more complex phytolith record from the Kuk site in the Highlands of New Guinea, several Musaceae taxa are distinguished, to the successive taxonomic levels of genus, section, species and subspecies. Bananas were present there by 10,000 B.P., and were cultivated by about of Pacific and Asian Studies, Australian National University, Canberra. 
7000 B.P. (Denham 2004, 2005; Denham et al. 2003, 2004; Lentfer 2003). More widely, phytolith evidence suggests that bananas had been carried to Africa, where there is no wild population of the genus $M u s a$, by 5000 years ago (Lejju et al. 2006). Because Pacific banana cultivars include members of two sections of the genus Musa, their archaeobotanical study by phytoliths and other means, such as the identification of seeds, is more complicated than anywhere else. This work is in its infancy (Ball et al. 2006; Bowdery 1999; Lentfer 2003; Lentfer and Green 2004; see Kennedy in press for background discussion and references).

Lack of archaeological evidence has not prevented the inclusion of bananas in hypotheses of Pacific colonization, most notably as part of the "transported landscapes" that Lapita colonists carried from the western Pacific in initial settlement of Polynesia (Kirch 1997:205, 218; Kirch and Green 2001:122-125). The basis for the inclusion of bananas among the first agricultural crops in Polynesia is the linguistic reconstruction of terms for two separate groups of Oceanic cultivated bananas, Fe'i and the rest (Kirch and Green 2001 : 123). Unfortunately, the reconstructions rest on a common but mistaken assumption that only the Fe' $\mathrm{i}$ group is indigenous in the New Guinea region (Kennedy in press; Ross 1996), and they do not specify the Pacific plantain group as distinctive. Given the formidable confusions of Western botanical banana terminology, linguistic reconstruction cannot at present be relied upon to make secure distinctions among bananas.

In the currently orthodox view of Pacific colonization, late Holocene populations supported by agriculture spread from Taiwan through the Philippines into Island Southeast Asia and the northern New Guinea region, and thence into Polynesia (Bellwood 2005; Kirch 2000). This once suggested that Southeast Asian- and New Guinea-derived groups of cultivated bananas coalesced in the western Pacific and were transmitted east together, along with the rest of the assemblage of Oceanic crop plants. But the unexpectedly complex parentage of the Pacific plantains does not support this scenario. This group of cultivated bananas has not yet drawn particular comment from Pacific archaeologists. In an earlier era of reflection on Polynesian origins, Simmonds had concluded that "So far as it goes ..., the evidence of bananas does not disagree with the concept of diverse origins for the Polynesians themselves" (1962:153).

This paper focuses on the domesticated bananas of the Pacific to show that their complex origins are inconsistent with current hypotheses concerning the origins and derivation of Oceanic food plants. As Simmonds had suggested, the traditional banana cultivars of Polynesia do indeed imply multiple dispersals from the west. At least three distinct lineages of domesticated bananas, all with partial New Guinea parentage, were transmitted prehistorically from the Southeast Asian/New Guinea region into eastern Oceania. There is currently no evidence bearing on the relative ages of these lineages, and none for their coexistence as part of an ancestral assemblage of crop plants in the New Guinea region, or elsewhere. For Pacific banana cultivars, as for other components of the Oceanic agricultural assemblage, the origins, timing, and assumed tight packaging, delivered in a single west-to-east colonizing episode, are all questionable (Anderson 2003:77; Dobney et al. 2007; Matthews 1996). So, too, are the overwhelming emphasis on movements to the east rather than west and the often asserted isolation of the New Guinea region until the late Holocene (Allaby 2007; Denham 2004; Grivet et al. 2004; Kennedy in press: 16; Kennedy and Clarke 2004:27). 


\section{WILD AND DOMESTICATED BANANAS}

Bananas all belong to the genus Musa, native to the Old World Tropics from eastern India to the Solomon Islands. The 50-plus wild species of the genus are colonizers of rainforest gaps and disturbances. Their fruit, berries of characteristic banana shape, are full of gravelly hard seeds with little pulp. Banana plants have many uses apart from their fruit. Leaves are widely used for wrapping and serving food. Flowers, buds, and occasionally corms and stems are used for food or medicine. The petioles provide fiber.

Domesticated bananas (that is, plants with edible fruit, relatively seedless, propagated vegetatively from suckers) are the result of a complex sequence of processes beginning with fruit that develop pulp without pollination (parthenocarpy), followed by suppression of seeds through mechanisms leading to both female and male sterility. Parthenocarpy, producing edible fruit, though sometimes with a few seeds, is the critical first step in banana domestication and is further discussed below. Both parthenocarpy and sterility are essential to the development of the typical seedless bananas of commerce. Wild bananas are diploid: cells have two sets of chromosomes. Triploids (three sets of chromosomes), especially of hybrid parentage, are more productive and much less likely to produce seeds. In seedless banana clones, variation can arise from mutations in body (somatic) cells and be propagated by planting suckers (Simmonds 1959:57-62). Such somatic mutation is an important source of variability among cultivars. The primary lever of human selective pressure throughout the sequence leading to edible bananas has been the propagation of plants by transplanting suckers (Purseglove 1975; Simmonds 1959, 1962), and this has also enabled their worldwide spread by human agency.

The parentage of edible bananas is more complex and confused than most short summaries suggest. The difficulties include uncertainties of the biogeography and ecology of wild bananas, exacerbated by very patchy collections, and the recently accumulating evidence that the standard morphotaxonomic classifications of banana cultivars sometimes disagree with classifications based on molecular markers (see Kennedy in press and references).

The domestication process in bananas involves only a few of the many wild species of the genus Musa. Nevertheless, it seems to have occurred independently in two sections of the genus, and to have involved more than one species within each of these sections. The genus was formerly divided into five sections, two of which, Australimusa and Eumusa, included domesticated bananas. These five sections have recently been reduced to three, with section Eumusa absorbed into section Musa and Australimusa into Callimusa (Wong et al. 2002). Wild species of these two revised sections both have eastern boundaries in the Solomons chain, section Callimusa extending west as far as Borneo and section Musa covering the full extent of the genus, as far west as eastern India.

The main wild species contributing to domesticated bananas, their labeling by genome and their conventional phylogenies are summarized in Tables 1 and 2.

Domesticated bananas belonging to section Callimusa are peculiar to the Pacific region. Widely distributed from New Guinea to Micronesia and eastern Polynesia but now unimportant in most places, they are known as the Fe'i group. Most have upright fruiting stems and rather squat, coppery-skinned fruit. They are further discussed below. 
Table i. Revised Taxonomy of Significant Wild Musa Species Contributing to EDIBLE BANANAS (IMPORTANT SPECIES BOLD)

\begin{tabular}{|c|c|c|c|c|c|}
\hline GENUS & $\begin{array}{c}\text { OLD } \\
\text { SECTION }\end{array}$ & $\begin{array}{c}\text { NEW } \\
\text { SECTION }\end{array}$ & SPECIES & $\begin{array}{l}\text { GENOME } \\
\text { LABEL }\end{array}$ & DISTRIBUTION \\
\hline \multirow[t]{5}{*}{ Musa } & \multirow[t]{3}{*}{ Australimusa ${ }^{1}$} & \multirow[t]{3}{*}{ Callimusa $^{1}$} & lolodensis & $\mathrm{T}$ & N New Guinea, Halmahera \\
\hline & & & maclayi $^{2}$ & $\mathrm{~T}$ & New Guinea, New Ireland, Solomons \\
\hline & & & peekelii $^{2}$ & $\mathrm{~T}$ & N New Guinea, New Ireland \\
\hline & \multirow[t]{2}{*}{ Eumusa } & \multirow[t]{2}{*}{ Musa } & acuminata $^{2,3}$ & A & $\begin{array}{l}\text { Sri Lanka, India, mainland and Island } \\
\text { SE Asia, SW Pacific, Australia }{ }^{4}\end{array}$ \\
\hline & & & balbisiana & B & $\begin{array}{l}\text { Sri Lanka, E India, Sikkim, mainland } \\
\text { SE Asia, S China, Philippines, E } \\
\text { New Guinea, New Britain }\end{array}$ \\
\hline
\end{tabular}

My collation of data from Argent 1976; Daniells et al. 2001; Jarret et al. 1992; Nasution 1993; Sharrock 2001; Simmonds 1962; and Wong et al. 2002.

1. Species affiliations of edible clones (Fe'i bananas) uncertain; multiple parentage likely.

2. Multiple subspecies.

3. See Table 5.

4. Outliers (Polynesia and Pemba) are human introductions.

The familiar supermarket banana and all other domesticated bananas except the $F e^{\prime} i$ group belong to section Musa. These bananas are much more widespread and diverse than the Fe'i group and provide important staple food in many tropical areas, as well as the commercial sweet cultivars.

Musa acuminata is clearly established as the primary wild parent of parthenocarpic bananas of section Musa, producing edible diploids designated AA in the standard labeling system devised by Simmonds and Shepherd (1955). Edible diploid bananas are often seedy if pollinated. Triploids (AAA) developed from these. Parthenocarpic diploids of Musa acuminata also hybridized with Musa balbisiana to produce $\mathrm{AB}$ diploids, $\mathrm{AAB}$, and $\mathrm{ABB}$ triploids.

Although it is clear that parthenocarpy within section Musa has occurred only in Musa acuminata, the parentage of the resulting edible bananas is greatly complicated by the diversity of Musa acuminata at subspecies level. Parthenocarpy probably developed in at least two of these subspecies, and there are many edible hybrids between these and additional wild subspecies. Hybridization between

Table 2. Outline of Conventional Phylogeny of Cultivated Bananas

\begin{tabular}{|c|c|c|c|c|}
\hline GENUS: & MUSA & MUSA & MUSA HYBRIDS & MUSA HYBRIDS \\
\hline SECTION: & MUSA & MUSA & $M U S A^{1}$ & CALLIMUSA ${ }^{1}$ \\
\hline SPECIES/HYBRIDS: & ACUMINATA & $B A L B I S I A N A$ & $\begin{array}{c}\text { ACUMINATA } \times \\
\text { BALBISIANA }\end{array}$ & $\begin{array}{c}\text { LOLODENSIS, MACLAYI, } \\
\text { PEEKELII }\end{array}$ \\
\hline $\begin{array}{l}\text { wild types } \\
\text { diploid cultivars } \\
\text { triploid cultivars } \\
\text { tetraploid cultivars }\end{array}$ & $\begin{array}{l}\text { AA } \\
\text { AA } \\
\text { AAA } \\
\text { AAAA }\end{array}$ & $\begin{array}{l}\mathrm{BB} \\
? \\
?\end{array}$ & $\begin{array}{l}? \\
\mathrm{AB} \\
\mathrm{AAB}, \mathrm{ABB} \\
\mathrm{AABB}\end{array}$ & $\begin{array}{l}\mathrm{TT} \\
\mathrm{TT}\left(\mathrm{Fe}^{\circ} \mathrm{i}\right) \\
?\end{array}$ \\
\hline
\end{tabular}

Based on Simmonds 1959; Sharrock 2001.

1. Musa $\times$ Callimusa edible hybrids also exist in Papua New Guinea: AT, AAT, ABBT. 
Musa acuminata and Musa balbisiana poses additional complications. This second parent species of some edible bananas is less well understood than Musa acuminata, and has not been divided into subspecies. Its distribution, wild/cultivated status, and genetic characterization are all problematic. Whether it is indigenous or introduced in Malaysia, Thailand, New Guinea, and the Philippines has been questioned (Argent 1976; De Langhe and de Maret 2000; Kennedy in press; Simmonds 1956). Claims of parthenocarpy are contradicted by DNA evidence (Carreel et al. 1994; Espino et al. 1991). The biogeography and genetic interrelationships of cultivated bananas are further discussed below.

Confusion of terms for edible bananas traces back at least to Linnaeus, whose two "species" were both hybrid cultivars with quite different characteristics (one a "plantain," the other a sweet banana) but the same genotype (AAB). The term plantain, often used in English to apply to any banana eaten cooked, is the source of particularly troublesome ambiguity, since, as Simmonds pointed out (1959:57), cooking is often "a matter of custom rather than necessity," and does not define any botanically meaningful class. The Fe' $i$ bananas, especially those of Tahiti, have sometimes been called "mountain plantains." As used by banana breeders, the term plantain applies to just one morphologically very distinctive group of hybrid bananas among those of AAB genotype, in the section Musa. This group is represented in the Pacific but is better known elsewhere, especially Africa.

\section{PACIFIC CULTIVATED BANANAS}

All the bananas of the Pacific east of the large islands of the Solomons (i.e., Remote Oceania; see Fig. 1) are human introductions. They include isolated occurrences of wild-type, seeded bananas of section Musa in Samoa and Hawai'i;

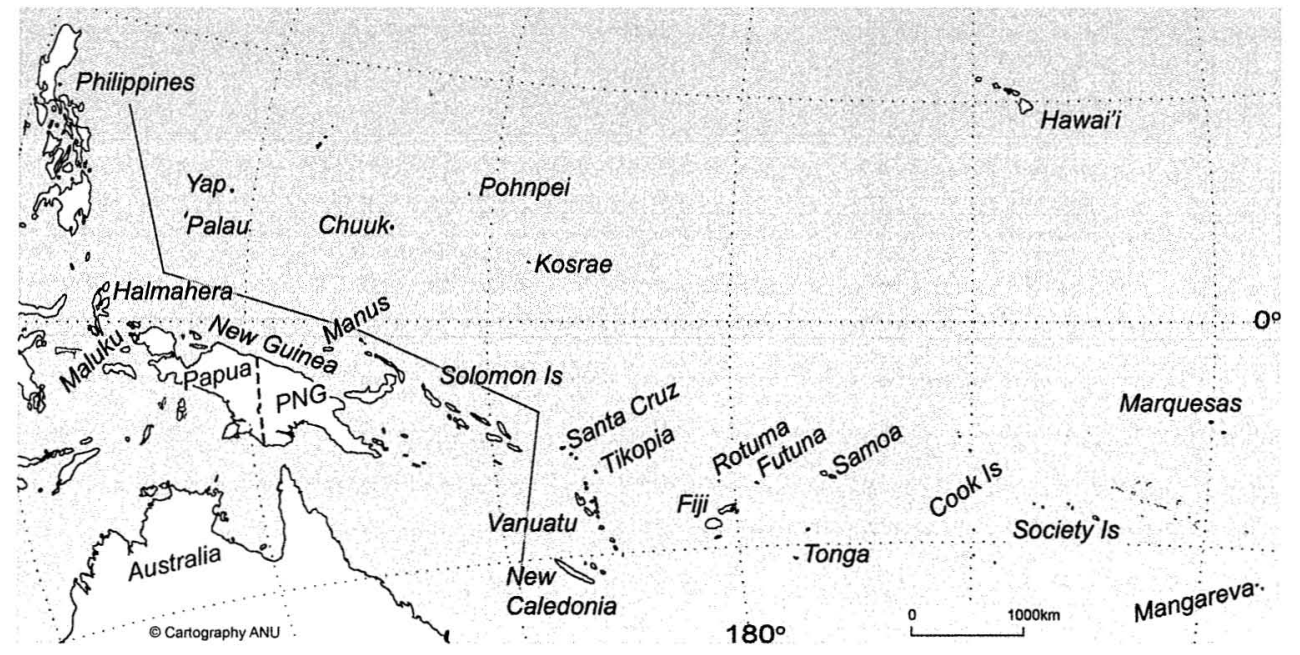

Fig. 1. Pacific Ocean locations. The solid line separates Near Oceania (west and south) from Remote Oceania, which includes Vanuatu, New Caledonia, Fiji, and all the islands of Polynesia and Micronesia. 
reports of wild, seeded Callimusa bananas have not been confirmed (Simmonds 1959:67). Many cultivars have been introduced since European contact, as ornamentals as well as for food. In some Pacific islands, bananas continue to be an important staple carbohydrate.

Simmonds' classic worldwide comparative survey (1959) of cultivated bananas drew attention to two distinctive groups of cultivated bananas in Polynesia regarded as pre-European introductions. These are the $\mathrm{Fe}^{\prime} \mathrm{i}$ group, section Callimusa, and the less well-known but more important group belonging to section Musa, which has come to be known as the Maia Maoli/Pōpō'ulu group or more loosely as the Pacific plantains (Lebot et al. 1993:164). The distributions of these groups are summarized in Figure 1 and Table 3. Because records providing

Table 3. Distribution of Pre-European Pacific Banana Cultivars and Selected REFERENCES

\begin{tabular}{|c|c|c|c|c|}
\hline & FE'I & REFERENCE & $\begin{array}{c}\text { PACIFIC } \\
\text { PLANTAIN }^{\mathrm{I}}\end{array}$ & REFERENCE \\
\hline Maluku & $?$ & $\begin{array}{l}\text { MacDaniels 1947; Simmonds } \\
1959\end{array}$ & & \\
\hline West Papua & $\mathrm{x}$ & Edison et al. 2002 & & \\
\hline PNG & $\mathrm{x}$ & $\begin{array}{l}\text { Arnaud and Horry 1997; } \\
\text { Simmonds } 1959\end{array}$ & $\mathrm{x}$ & $\begin{array}{l}\text { Arnaud and Horry 1997; Daniells } \\
\text { 1990; Daniells et al. } 2001\end{array}$ \\
\hline Solomons & $\mathrm{x}$ & Simmonds 1959; Yen 1973 & & \\
\hline Santa Cruz & $\mathrm{x}$ & Yen 1973 & ? & Yen 1973 \\
\hline Vanuatu & $\mathrm{x}$ & Barrau 1962; Simmonds 1959 & $\mathrm{x}$ & Lebot et al. 1993 \\
\hline $\begin{array}{l}\text { New } \\
\quad \text { Caledonia }\end{array}$ & $\mathrm{x}$ & $\begin{array}{l}\text { Barrau 1962; Kagy 1998; } \\
\text { Simmonds } 1959\end{array}$ & $\mathrm{P}$ & $\begin{array}{l}\text { Kagy 1998; Kagy and Carreel } \\
\text { 2004; Lebot et al. } 1993\end{array}$ \\
\hline Palau & $\mathrm{x}$ & Barrau 1962 & & \\
\hline Yap & $\mathrm{x}$ & Barrau 1962 & $\mathrm{x}$ & Daniells 2004 \\
\hline Chuuk & $\mathrm{x}$ & Englberger et al. 2003 & & \\
\hline Pohnpei & $\mathrm{x}$ & Englberger and Lorens 2004 & $\mathrm{x}$ & Englberger and Lorens 2004 \\
\hline Kosrae & $\mathrm{x}$ & Simmonds 1959 & $\mathrm{x}$ & Daniells 2004 \\
\hline Tikopia & $\mathrm{x}$ & Kirch and Yen 1982 & & \\
\hline Fiji & $\mathrm{x}$ & Simmonds 1959 & $\mathrm{x}$ & Simmonds 1959 \\
\hline Rotuma & $\mathrm{x}$ & McClatchey et al. 2000 & $?$ & McClatchey et al. 2000 \\
\hline Futuna & $\mathrm{x}$ & Kirch 1994 & $?$ & Kirch 1994 \\
\hline Tonga & $\mathrm{x}$ & Simmonds 1959 & $\mathrm{x}$ & Daniells 1990 \\
\hline Samoa & $\mathrm{x}$ & $\begin{array}{l}\text { Daniells 1990; Simmonds } \\
1959\end{array}$ & $\mathrm{P}$ & Daniells 1990; Simmonds 1959 \\
\hline Cook Is. & $\mathrm{x}$ & $\begin{array}{l}\text { Daniells 1990; Simmonds } \\
1959\end{array}$ & $\mathrm{P}$ & Daniells 1990; Daniells et al. 2001 \\
\hline Society Is. & $\mathrm{P}$ & $\begin{array}{c}\text { MacDaniels 1947; Sharrock } \\
\text { 2001; Simmonds } 1959\end{array}$ & $\mathrm{P}$ & Lebot et al. 1994; Lepofsky 2003 \\
\hline Mangareva & $\mathrm{x}$ & MacDaniels 1947 & & \\
\hline Marquesas & $\mathrm{P}$ & $\begin{array}{l}\text { MacDaniels 1947; Simmonds } \\
1959\end{array}$ & $\mathrm{P}$ & Lebot et al. 1994 \\
\hline Hawai'i & $\mathrm{r}$ & Simmonds 1954, 1959 & $\mathrm{P}$ & $\begin{array}{l}\text { Lebot et al. 1994; Simmonds } \\
\qquad \text { 1954, 1959; Ploetz et al. } 2007\end{array}$ \\
\hline
\end{tabular}

key: $\mathrm{P}=$ important, $\mathrm{x}=$ present, ? = uncertain, $\mathrm{r}=$ recent introduction.

1. Also known as the Maia Maoli/Pōpō'ulu group but including Iholena and allies (Daniells 1990; De Langhe and de Maret 2000; Lebot et al. 1993, 1994; Ploetz et al. 2007). 
detailed characterization of the Pacific plantains are rare, their listing is certainly incomplete. It is possible that other cultivars of section Musa were also prehistoric introductions to Remote Oceania, but early descriptions are too vague to establish this.

\section{Fe'i Bananas}

Simmonds' account of the Fe'i group (1959:65-75) drew heavily on MacDaniels (1947), whose study of the Tahitian cultivars is the most comprehensive. Grown in the montane valleys of the Society Islands, these were once an important staple food source. After population shifts toward the coast, they continued to be harvested from old established plants. Sometimes described as wild, their nearly complete sterility is unequivocal evidence of domestication. Although their former management and propagation are undescribed, it is unlikely that they could persist for very long without at least minimal tending to prevent overshadowing (Lepofsky 2003). The proliferation of cultivars (13) in Tahiti suggests the possibility of a localized star-burst of clones derived by somatic mutations (Simmonds 1959:71-72). Fe'i bananas have become rare in Micronesia and are threatened in Chuuk. In Pohnpei, where there are several cultivars, they are being promoted as a dietary source of $\beta$-carotene (Englberger and Lorens 2004; Englberger et al. 2003). In Santa Cruz, in the Southeast Solomons, Yen (1974) recorded 13 cultivars.

Although Fe'i cultivars are clearly widely distributed throughout the Pacific, they are very poorly described. Often said to be edible only when cooked, they are sometimes esteemed as raw fruit (Kennedy and Clarke 2004). They are probably widely threatened by habitat destruction, introduced diseases and neglect, as in Tahiti (Sharrock 2001; Simmonds 1959).

As noted above, recent genetic evidence supports an origin in the New Guinea region for the Fe'i cultivars, as originally proposed by MacDaniels (1947). Morphological similarity of $\mathrm{Fe}^{6} \mathrm{i}$ cultivars and Musa maclayi had suggested that this was the main parent, if not the only one (Simmonds 1962). But DNA polymorphisms of Fe'i cultivars suggest they are hybrids among several Callimusa species (Jarret et al. 1992; Sharrock 2001). It is not clear whether parthenocarpy occurred in just one or more than one of these. Neither is it clear whether Fe'i cultivars include triploids as well as diploids. Since the wild parent species are restricted to Halmahera and the northern New Guinea region as far east as the Solomons, this is probably the area of origin of the Fe' $i$ cultivars. They are a highly selected group, some having entirely lost the male floral axis, and they must have been distributed by human transport of suckers (Simmonds 1959:66-67).

There is no archaeological record suggestive of the cultivation of Fe' $i$ bananas anywhere. Although their phytoliths are distinctive, they have been identified only rarely (Kennedy in press; Lentfer 2003; Lentfer and Green 2004). Further study of this group is needed.

\section{Pacific Plantains}

The cultivated bananas of section Musa form a very complex set, understanding of which is bedeviled by the proliferation of Linnaean binomials misapplied to ster- 
ile, hybrid clones. As more has been learned about these, classification has become increasingly contentious among experts. No wonder, then, that non-specialists have often retreated to simplification, content to speak of bananas rather than to identify any particular subset.

Recognition of the group that has come to be called the Maia Maoli/Pōpó'ulu group, or more inclusively the Pacific plantains, began with re-examination of pre-European Hawai'ian cultivars (Simmonds 1954), and comparison of these with others in Polynesia and elsewhere. Simmonds distinguished three groups of clones in Hawai' $i$, designated Maia Maoli (maia is a Hawai'ian term for banana), Popō'ulu and Iholena, from the Hawai'ian names of the most important cultivar in each group. The first two he classed as triploid hybrids (AAB), Pōpō'ulu having shorter, thicker, blunt-ended fruit and fewer clones than the Maoli group. He associated them with Samoan and Fijian cultivars, and a single Philippine one, and suggested that since he had found no counterparts for them in New Guinea, or west of the Philippines in Southeast Asia, the Philippines was the most likely source (Simmonds 1959:103-106). He also thought that these hybrids were likely to have been the first taken into the Pacific (Simmonds 1959:92-93). The Iholena cultivars of Hawai'i Simmonds (1959:105) thought stood apart from the others, and he made no comment about their origin.

These Polynesian bananas are more widespread than Simmonds recorded (Table 3). Their terminology remains confused. Iholena has been shown to be a plantain-like hybrid (AAB), sometimes included among the Pacific plantain group (Kagy and Carreel 2004; Lebot et al. 1993:164). Maia Maoli and Pōpō'ulu are sometimes reduced to a single group (Daniells 1990, 1995; Daniells et al. 2001; De Langhe and de Maret 2000). Other recorded Polynesian terminologies do not make the distinctions reflected by the three Hawai'ian terms (Lebot et al. 1994). Thus, it should be emphasized that because these terms have been appropriated as group labels in banana taxonomy, individual clones with cognate names do not necessarily belong to the same group. Table 4 and Figure 1 show the recorded distributions of the three groups.

Table 4. Distribution of Pacific Plantain Groups

\begin{tabular}{lccc}
\hline & MAIA MAOLI & PŌPŌ'ULU & IHOLENA \\
\hline PNG & $\mathrm{p}$ & & $\mathrm{p}$ \\
Vanuatu & $\mathrm{p}$ & $\mathrm{p}$ & $\mathrm{p}$ \\
New Caledonia & $\mathrm{p}$ & $\mathrm{p}$ & \\
Yap & $\mathrm{u}$ & $\mathrm{u}$ & \\
Pohnpei & $\mathrm{u}$ & $\mathrm{u}$ & $\mathrm{p}$ \\
Kosrae & $\mathrm{u}$ & $\mathrm{u}$ & $\mathrm{p}$ \\
Tonga & $\mathrm{p}$ & $\mathrm{p}$ & $\mathrm{p}$ \\
Samoa & $\mathrm{u}$ & $\mathrm{u}$ & \\
Cook Is. & $\mathrm{p}$ & $\mathrm{p}$ & $\mathrm{p}$ \\
Society Is. & $\mathrm{p}$ & $\mathrm{p}$ & $\mathrm{p}$ \\
Marquesas & $\mathrm{p}$ & $\mathrm{p}$ & \\
Hawai'i & $\mathrm{p}$ & $\mathrm{p}$ &
\end{tabular}

$\mathrm{p}=$ present, $\mathrm{u}=$ present but Maia Maoli and Pōpōulu not differentiated; based on Daniells 1990, 2004; Daniells et al. 2001; Lebot et al. 1993, 1994; Kagy and Carreel 2004; and Ploetz et al. 2007. 
The Pacific plantains are virtually sterile. Like the Fe'i bananas, they were undoubtedly spread through the Pacific by human agency, and have subsequently developed minor variants by somatic mutation. They remain poorly described and were largely ignored until recently. Recent DNA research has established their relationship not only with bananas of the New Guinea region, but with the African plantains. One group, Maia Maoli, is a complex three-way rather than twoway hybrid.

\section{BANANA ORIGINS REVISED}

As noted above, there is no doubt that Musa acuminata is the main parent of the edible bananas of section Musa, but geographic variation at subspecies level greatly complicates the question of origins. Subspecies are shown in Table 5, those in which parthenocarpy developed in bold. Simmonds emphasized Musa acuminata malaccensis as the main, though perhaps not the only taxon in which parthenocarpic diploids originated. Triploid forms (AAA) developed from these, and edible diploids, still partially fertile, were spread by cultivation into the range of Musa balbisiana, producing triploid hybrids ( $\mathrm{AAB}$ and $\mathrm{ABB}$ ), especially in India but also in the Philippines (Simmonds 1959:125, 309; 1962:140). Simmonds' recognition (1959:92) that the Pacific plantains were unlike other $\mathrm{AAB}$ hybrids, and possibly derived from the Philippines, passed largely unnoticed in the face of the orthodox derivation of most edible bananas of section Musa from western Southeast Asia, centered on the Malay Peninsula.

The orthodox view that the Malay Peninsula was the primary center of development of the edible bananas of section Musa applied particularly to the clones grown for international trade, especially Gros Michel and Cavendish. Although New Guinea itself was notable, at least to banana taxonomists, for its proliferation of edible diploid bananas of section Musa, their parentage was not a pressing issue, and local origin was not ruled out (Argent 1976; Kennedy in press; Simmonds

Table 5. Wild Musa acuminata Subspecies and Their Distributions

\begin{tabular}{|c|c|}
\hline SUBSPECIES & DISTRIBUTION \\
\hline banksii $^{1}$ & New Guinea, Manus, N. Australia \\
\hline burmannica & E. India, Burma, Thailand, ?Sri Lanka \\
\hline burmannicoides & E. India, Burma, Thailand \\
\hline errans $^{2}$ & Philippines \\
\hline malaccensis & Malay Peninsula (lowlands), Thailand \\
\hline microcarpa & Borneo $^{3}$ \\
\hline siamea & Thailand, Malay Peninsula, Viet Nam \\
\hline truncata & Malay Peninsula (highlands) \\
\hline zebrina & Indonesia ${ }^{3}$ \\
\hline
\end{tabular}

Data from Argent 1976; Daniells et al. 2001; Pollefeys et al. 2004; Valmayor 2001; and Wong et al. 2001. Parthenocarpic species bold.

1. Raised to species rank by Argent (1976) and others.

2. Genetically distinct from $M$. banksii but morphologically similar; sometimes confused in the literature.

3. There are probably more Indonesian subspecies than shown (Nasution 1991). 
1959:126, 331, 1962:140; Yen 1993). Nevertheless, it came to be accepted that these and other edible bananas of section Musa were introduced to the New Guinea region from Southeast Asia and then to Remote Oceania (Golson 1977:601-602; Ross 1996; Yen 1973, 1982). Sometimes, it was assumed that there were no indigenous bananas in the New Guinea region, wild or cultivated, belonging to section Musa (Wilson 1985), despite the evidence to the contrary (Argent 1976; Simmonds 1962; see Kennedy in press for extended discussion).

From the mid-1980s, renewed interest in Pacific bananas was generated by international strategies to improve germplasm collections in the face of increasingly devastating fungal diseases. New collecting expeditions to Papua New Guinea, in particular, expanded known distributions and recorded many new cultivars (Arnaud and Horry 1997; Daniells 1990; Sharrock 1990, 1995). These new data undermine Simmonds' perception (1959:92) that the Pacific plantains had no counterpart in Papua New Guinea, and hypotheses based on this (De Langhe and de Maret 2000; Lentfer and Green 2004).

The biogeographical hypothesis of western Malaysian dominance in the parentage of edible bananas was first questioned by analyses of pigments and enzymes, which showed that the Pacific plantains matched Musa acuminata ssp. banksii and thus originated in the New Guinea region (Horry and Jay 1988; Lebot 1999; Lebot et al. 1993, 1994). This result has been confirmed, refined and extended by analyses of DNA, which show that the A genomes of almost all edible bananas are related to the eastern subspecies banksii (New Guinea) and errans (Philippines) of Musa acuminata, and that some cultivars are complex hybrids among Musa acuminata subspecies (Carreel et al. 1994; D'Hont et al. 2000; Raboin et al. 2005). The two eastern Musa acuminata subspecies, errans and banksii, have similar morphological characteristics and have often been confused (Kennedy in press and references; Lebot 1999). Differences in several DNA markers establish them as separate (Carreel et al. 2002; Kagy and Carreel 2004).

In the most comprehensive study of relationships among wild and cultivated bananas so far, cytoplasmic DNA, both mitochondrial (paternal) and chloroplastic (maternal), of 305 wild, diploid, and triploid accessions was analysed. The major conclusion is that the parthenocarpic A genomes of almost all the edible banana groups derive from either subspecies banksii or errans of Musa acuminata (or from both of them) (Carreel et al. 2002). This shifts the primary center of banana domestication eastward to the Philippines-New Guinea region, and contradicts the common assumption that New Guinea was isolated from the mainstream of banana domestication. Almost all of the cultivars analyzed share DNA with the eastern subspecies errans (Philippines) and banksii (New Guinea region), rather than with the expected western subspecies, especially malaccensis. These easternderived cultivars include many edible diploids (AA), both the African and the $\mathrm{Pa}-$ cific plantains (AAB), the cooking/beer bananas of the East African Highlands (AAA), as well as the sweet bananas of modern commerce, Gros Michel and Cavendish (both also AAA).

These relationships are outlined in Table 6, which simplifies and summarizes the data of Carreel et al. (2002: Tables 1 and 2) to highlight the relationships of the Pacific plantains. The four wild subspecies shown (bold) include all those with which significant numbers of cultivars are grouped. Cultivars are related maternally across rows and paternally down columns. In the Pōpō'ulu and Iholena 
Table 6. Classification of Selected Wild and Cultivated Bananas According to their Maternal (Chloroplast) and Paternal (mitochondrial) Relationships,

Determined By RFLP ${ }^{I}$ ANALYSES

MITOCHONDRIAL

TYPE:

$(\text { PATERNAL })^{2}$

\begin{tabular}{|c|c|c|c|}
\hline$\alpha$ & $\delta$ & $\varepsilon$ & $\phi$ \\
\hline & & zebrina & \\
\hline $\begin{array}{l}\frac{\text { errans }}{\text { AA [36] }}{ }^{4} \\
\text { AAA: } \\
\text { Gros Michel }{ }^{5}[6] \\
\text { Cavendish }^{5}[7]\end{array}$ & $\begin{array}{l}\text { malaccensis } \\
\text { AA [2] } \\
\text { AAB: } \\
\text { Silk }^{6}[2]\end{array}$ & $\mathrm{AA}[1]$ & $\mathrm{AA}[3]$ \\
\hline $\begin{array}{l}\text { AA [49] } \\
\text { AAB: } \\
\text { Pacific plantains: } \\
\text { (Maia Maoli) [1] }\end{array}$ & & $\begin{array}{l}\text { AAA: } \\
\text { E African Highland [9] }\end{array}$ & $\begin{array}{l}\text { banksii } \\
\text { AA [18] } \\
\text { AAB: } \\
\text { African plantains [5] } \\
\text { Pacific plantains: } \\
\text { (Pōpóculu) [2] } \\
\text { (Iholena) [1] }\end{array}$ \\
\hline
\end{tabular}

Data from Carreel et al. 2002: Tables 1 and 2. Wild subspecies bold, those developing parthenocarpy underlined.

1. Restriction fragment length polymorphism.

2. Four of the nine mitochondrial types shown in the original data.

3. Three of the ten chloroplast patterns shown in the original data.

4. $[\mathrm{n}]=$ number of accessions in each group.

5. Commercial dessert cultivars: Cavendish has largely replaced Gros Michel, production of which was severely affected by Panama disease.

6. Dessert cultivar, much prized and widespread in the tropics, but seldom commercially grown.

groups of Pacific plantains and the African plantains, both the maternal and paternal A genomes match those of Musa acuminata ssp. banksii. In the Maia Maoli group, the maternal A genome again matches Musa acuminata ssp. banksii, but the paternal A genome is related to Musa acuminata ssp. errans. With a B genome of unknown provenience, it is thus a three-way hybrid. The data do not resolve the $\mathrm{B}$ genome of any of these hybrids.

The modern commercial sweet bananas (Cavendish and Gros Michel) also have a complex origin, involving secondary hybridization between parthenocarpic diploids of Musa acuminata ssp. errans derivation, pollinated by one or more of the western Musa acuminata subspecies (not all of these are shown in Table 6). They might have developed later than the plantains (Kagy and Carreel 2004; Raboin et al. 2005). The morphologically distinctive East African Highlands bananas are separated from other AAA groups: their cytoplasmic DNA implies they are hybrids related maternally to Musa acuminata ssp. banksii, pollinated by Indonesian Musa acuminata ssp. zebrina.

The New Guinea-Philippine derivation of the A genome of so many banana cultivars is unexpected. It suggests that the first step in banana domestication involved the human transmission of parthenocarpic AA diploid bananas to the west and northwest across Island Southeast Asia, through Maluku to the Philippines and the rest of Indonesia and Malaysia, rather than in the reverse direction 
(Fig. 1). The New Guinea parentage of the A genome of both the African and Pacific plantains is particularly striking. Because the distribution and genetic diversity of Musa balbisiana are so poorly understood, there is no evidence to show where hybridization with this species occurred, or whether this happened only once.

Among the edible bananas of section Musa, the African and Pacific plantains and the East African Highlands bananas have all been considered candidates for early dispersal, on the grounds that each forms a distinctive group which has accumulated local variations (Daniells et al. 2001; De Langhe et al. 1994-1995, 2005; Noyer et al. 2005; Simmonds 1959). The discovery that all of them share a maternal A genome derived from Musa acuminata banksii implies a quite unexpected distribution centered on New Guinea.

\section{COMPLEX ORIGINS, MULTIPLE DISPERSALS IN THE PACIFIC?}

Which bananas were first transmitted to Polynesia? Answering this question requires disentangling the phylogenies of the likely candidates that the recent genetic studies have clarified. But much more information is needed on both the timing and the locations of the implied genetic changes. While there is no doubt that the significant candidates all share a link in the New Guinea region, there is neither genetic nor archaeological evidence to show that these all coexisted during the Lapita phase in Near Oceania, or elsewhere. The inference that such a package existed, on linguistic or other grounds, must take account of the newly discovered genetic complexity of Pacific bananas.

Genetic diversity arising at several taxonomic levels distinguishes multiple lineages of cultivated bananas. At the highest level, parthenocarpy, the first step toward edibility, occurred independently in two sections of the genus, tracing to Musa acuminata in section Musa, and to one or more undetermined species in section Callimusa. Pacific cultivated bananas are unique in their derivation from both these sections of genus Musa. At the next level down, hybridization among species is likely in the parentage of the Callimusa section Fe'i bananas, and is certain in the Musa section Pacific plantains, which have both Musa acuminata and Musa balbisiana parentage. The diversity of subspecies in Musa acuminata adds yet another level: the Maia Maoli group of the Pacific plantains has both banksii and errans parentage. Lastly, somatic mutations in cultivars have given rise to further minor but sometimes conspicuous variation, propagated vegetatively by alert humans. This last level is the only mechanism which can produce variation in areas where there are no fertile wild species, such as the New World, where commercial bananas were pioneered (Simmonds 1959:308-333), Africa, and Remote Oceania. The distinctive purple-black sheaths and midribs, variegated leaves, and dichotomous inflorescences of some Hawai'ian clones are examples of variants established by somatic mutation (Simmonds 1959:57-60).

The DNA evidence summarized above shows that there is considerable genetic diversity at the level of subspecies or above in the Pacific plantains. Their A genomes show that they form two lineages, one derived from the New Guinea subspecies, the other a New Guinea-Philippine hybrid. Both of these lineages must have been carried by humans into Remote Oceania, because their wild parents are absent there. The Fe'i group, itself likely to be complex, constitutes another 
separate lineage. Thus, at least three genetically separate lines of edible bananas were introduced to Remote Oceania in prehistoric times. But there is no evidence to show they were transmitted together. Furthermore, while the genetic data and species distributions tell us where parthenocarpy developed, and limit the ranges within which the subsequent hybridizations might have occurred, the geographic details remain problematic.

\section{Where?}

The New Guinea region is clearly the primary source of the Fe'i bananas of Remote Oceania, although their parentage is uncertain. However, since hybridization among species and subspecies is very likely in the development of these bananas, its geography could also be complex. Although relatively uncommon, $F^{6} i$ bananas are found throughout Papua New Guinea and also in the Indonesian province of Papua (Arnaud and Horry 1997; Edison et al. 2002). They are not recorded farther west.

The geography of development of the Pacific plantains is also very hard to pin down. Parthenocarpic forms of Musa acuminata banksii are their primary component, which links them to the New Guinea region. But where the Musa acuminata errans contribution was added cannot be determined on present evidence. Transport of at least one of these subspecies between New Guinea and the Philippines is required by the parentage of the Maia Maoli group (Kagy and Carreel $2004: 32$ ), but in which direction is quite unclear. The distribution of Musa balbisiana is even more problematic, and has probably been greatly affected by human transport and habitat disturbance (see Kennedy in press for further discussion and references). Again, where it hybridized with one or more parthenocarpic Musa acuminata subspecies is quite uncertain.

Since the locations of these hybridizations in the Pacific plantains are unknown, it is premature to assume that the two Pacific plantain lineages developed together. The genetic evidence specifies the components but neither the location nor the order of their assembly. Where and when the two lineages first occurred together is unknown. Evidence of early linkage of the Pacific plantains with the Fe' $i$ bananas is also nonexistent, despite their common source in the New Guinea region. There is no sign of an early spread westward of Fe' $\mathrm{i}$ bananas, to parallel that of the Musa acuminata banksii-derived A genome. This implies that early Fe' $\mathrm{i}$ and banksii-derived cultivars developed separately.

Much remains to be learned about bananas throughout Southeast Asia. However, on present biogeographic, genetic or archaeological evidence, there is nothing to suggest that Taiwan or the adjacent coast of China played any significant role in the development of cultivated bananas. Evidence from the Philippines is also lacking, apart from the genetic evidence of the contribution of Musa acuminata errans to cultivated bananas, including the Maia Maoli cultivars of the Pacific.

As noted above, it is striking that the same New Guinea-derived A genome is shared by the Pacific plantains and both the African plantains and the other distinctive African bananas, the East African Highlands group. This clearly indicates this genome's spread west as well as east. All three groups have accumulated considerable differentiation by somatic mutations (Daniells et al. 2001), implying that their dispersal is relatively old. 
Useful dates for the presence of edible bananas come from contexts containing banana phytoliths that, for one reason or another, are unlikely to be from wild bananas. Although wild and cultivated forms of bananas have not so far been distinguished on the basis of the size or shape of phytoliths, this has been raised as a possibility (Ball et al. 2006; Vrydaghs and De Langhe 2003). At Kuk, in the New Guinea Highlands, where there are wild Musa species, the relative frequencies of grass and banana phytoliths about 7000 years ago provide the basis for suggesting banana cultivation. The distinctive morphologies of phytoliths from seeds distinguish among three species of Musaceae in the Kuk sequence, establishing the presence of Musa acuminata banksii and the absence of species belonging to section Callimusa (Denham 2004, 2005; Denham et al. 2003, 2004; Lentfer 2003). This suggests that edible diploids derived from Musa acuminata banksii may have developed by 7000 years ago.

In two African sites, in which wild bananas can be ruled out, the presence of Musa phytoliths supports the argument for cultivated bananas (Lejju et al. 2006; Mbida et al. 2000, 2001). Here, dates of 2500 to 5000 years ago are much older than expected for bananas in Africa. The phytoliths are identified to genus level, not below. Parsimony suggests that these phytoliths should derive from bananas known to be long-established in Africa, such as the East African Highlands and African plantain groups. The shared New Guinea-derived A genome of these and the Pacific plantains might therefore suggest that parthenocarpic forms of Musa acuminata banksii had developed more than 5000 years ago, consistent with the date of inferred banana cultivation at Kuk. Thus, bananas of section Musa, including antecedents of the Pacific plantains, were probably in cultivation long before any human movement into Remote Oceania.

Taking the East African date of 5000 years ago at face value, the transmission of edible bananas westward before then is as striking a proposition for Island Southeast Asian as for African prehistory. However, current knowledge of prehistoric plant utilization in Southeast Asia is too weak to provide a useful context for this implication.

There is no evidence to date the development of Musa acuminata $\times$ balbisiana hybrids with any precision, beyond the suggestion that both the African and $\mathrm{Pa}-$ cific plantains have diversified over relatively long periods since their dispersal. Phytoliths of Musa balbisiana, which may be distinguishable from those of Musa acuminata (Ball et al. 2006), have yet to be identified in archaeological contexts. It is not yet clear whether hybrids are archaeobotanically distinguishable.

Neither Kuk nor any other site provides clear phytolith evidence for cultivation of the section Callimusa-derived Fe' $i$ bananas, and there is no evidence at present to suggest whether these developed earlier or later than the bananas of section Musa. Because of these chronological unknowns, plus the geographical ones outlined above, the claim that the $\mathrm{Fe}^{\prime} \mathrm{i}$ bananas and the two lineages of Pacific plantains were brought together in the Near Oceanic Lapita phase of Pacific colonization, and transmitted to Remote Oceania among the founding suite of crops, is not supported by the current evidence. The hypothesis that all three banana lineages were present in the Lapita phase is not excluded, but it is a strong claim requiring a great deal more research to establish which bananas were where, and when. 


\section{CONCLUSION}

The cultivated Pacific bananas are unique in their high-level diversity, and what is known of their parentage suggests geographically dispersed development. There is no evidence that those transmitted to Remote Oceania were brought together as part of an ancestral suite of crops in Near Oceania. Instead, as the genetic evidence hints, an ancient pattern of human transmissions of cultivated bananas between New Guinea and the Philippines, and from both of these westward into Island Southeast Asia may have enabled continuous renewal, modification, and replacement, producing locally differentiated but ever-changing assemblages of banana cultivars. These westward movements from the New Guinea region apparently predated the spread of Lapita pottery. On current evidence, it is impossible to associate any particular banana lineage with this pottery. The extension of a pattern of complex interchanges eastward across the Pacific, and the gradual accretion in Remote Oceania of banana clones from different sources, is more plausible than a single uniquely diverse package.

Such a pattern of transmission suggests human contacts which should be reflected in archaeological data, including other resource distributions and material culture. Archaeological research capable of identifying such contacts has barely begun in much of the western Pacific fringe. Most urgently, across the whole region, we need much more detailed evidence of plant foods, which can only come from expanded archaeological investigation.

\section{ACKNOWLEDGMENTS}

Many people have provided help and encouragement in the work leading to this paper and to its final form. I thank especially David Addison, Doreen Bowdery, Françoise Carreel, Bill Clarke, Jeff Daniells, Andrew Fairbairn, Jack Golson, Robin Hide, Vincent Lebot, Will McClatchey, Matiu Prebble, Anne Underhill, Peter White, and Douglas Yen. Remaining confusions and mistakes are my responsibility.

\section{REFERENCES CITED}

Allaby, R.

2007 Origins of plant exploitation in Near Oceania: A review, in Genes, language and culture history in the Southwest Pacific: 181-198, ed. J. Friedlaender. New York: Oxford University Press.

Anderson, A. J.

2003 Initial human dispersal in Remote Oceania: Pattern and explanation, in Pacific archaeology: Assessments and prospects: 71-84, ed. C. Sand. Les Cahiers de l'Archéologie en Nouvelle Calédonie, 15. Nouméa: Service des Musées et du Patrimoine.

Argent, G.C.G.

1976 The wild bananas of New Guinea. Notes from the Royal Botanic Garden, Edinburgh 35:77114.

Arnaud, E., AND J.-P. Horry, eds.

1997 Musalogue: A catalogue of Musa germplasm. Papua New Guinea collecting expeditions, 19881989. Montpellier: International Network for the Improvement of Banana and Plantain.

Ball, T., L. Vrydaghs, I. Van Den Hauwe, J. Manwaring, and E. De Langhe

2006 Differentiating banana phytoliths: Wild and edible Musa acuminata and Musa balbisiana. Journal of Archaeological Science 33:1228-1236.

BARRAU, J.

1962 Les plantes alimentaires de l'Océanie: Origines, distribution et usages. Marseilles: Annales du Musée Colonial de Marseille. 
1965 Histoire et préhistoire horticoles de l'Océanie tropicale. Journal de la Société des Océanistes $21: 55-78$.

BELLWOOD, P. S.

2005 First farmers: The origins of agricultural societies. Oxford: Blackwell.

BOWDERY, D.

1999 Phytoliths from tropical sediments: Reports from Southeast Asia and Papua New Guinea. Bulletin of the Indo Pacific Prehistory Association 18:159-167.

Carreel, F., S. Fauré, D. González de Léon, P. Lagoda, X. Perrier, F. Bakry, H. Tézenas du Montcel, C. Lanaud and J.-P. Horry

1994 Évaluation de la diversité génétique chez les bananiers diploïdes (Musa ssp.). Genetics Selection Evolution 26 (Supplement 1):125s-136s.

Carreel, F., D. González de Léon, P. Lagoda, C. Lanaud, C. Jenny, J.-P. Horry and H. TézeNAS DU MONTCEL

2002 Ascertaining maternal and paternal lineage within Musa by chloroplast and mitochondrial DNA RFLP analyses. Genome 45:679-692.

Cummings, L. S.

1998 A review of recent pollen and phytolith studies from various contexts on Easter Island, in Easter Island in the Pacific context. South Seas symposium: 100-106, ed. C. M. Stevenson, G. Lee, and F. J. Marin. Santa Barbara: Easter Island Foundation.

D'Hont, A., A. Paget-Goy, J. Escoute, and F. Carreel

2000 The interspecific genome structure of cultivated banana, Musa spp. revealed by genomic DNA in situ hybridization. Theoretical and Applied Genetics 100:177-183.

Daniells, J.

1990 The banana varieties of Tonga, Western Samoa and the Cook Islands. Musarama 3(1):610.

1995 Illustrated guide to the identification of banana varieties in the South Pacific. Canberra, Australian Centre for International Agricultural Research.

2004 Consultancy report on training in the identification and characterization of banana varieties and development of the banana industry in Pohnpei, Federated States of Micronesia, prepared for the Island Food Community of Pohnpei.

Daniells, J., C. Jenny, D. Karamura, and K. Tomekpe

2001 Musalogue: A catalogue of Musa germplasm. Diversity in the genus Musa. Montpellier: International Network for the Improvement of Banana and Plantain.

De Langhe, E., and P. De Maret

2000 Tracking the banana: Its significance in early agriculture, in The prehistory of food: Appetites for change: 377-396, ed. C. Gosden and J. Hather. London and New York: Routledge.

De Langhe, E., M. Pillay, A. Tenkouano, and R. Swennen

2005 Integrating morphological and molecular taxonomy in Musa: The African plantains (Musa spp. AAB group). Plant Systematics and Evolution 255:225-236.

De Langhe, E., R. Swennen, and D. Vuylsteke

1994- Plantain in the early Bantu world. Azania 29/30:147-160.

1995

Denham, T.

2004 The roots of agriculture and arboriculture in New Guinea: Looking beyond Austronesian expansion, Neolithic packages and indigenous origins. World Archaeology 36(4):610-620.

Denham, T.

2005 Envisaging early agriculture in the Highlands of New Guinea: Landscapes, plants and practices. World Archaeology 37(2):290-306.

Denham, T., S. G. Haberle, C. J. Lentfer, R. Fullagar, J. Field, M. Therin, N. Porch, and B.

WINSBOROUGH

2003 Origins of agriculture at Kuk Swamp in the Highlands of New Guinea. Science 301:189193.

Denham, T., S. G. Haberle, and C. J. Lentfer

2004 New evidence and revised interpretations of early agriculture in Highland New Guinea. Antiquity 78(302): 839-857. 
Dobney, K., T. Cucchi, and G. Larson

2007 The pigs of Island Southeast Asia and the Pacific: New evidence for taxonomic status and human-mediated dispersal. This volume.

Edison, H. S., A. Sutanto, C. Hermanto, H. Lakuy, and Y. Rumsarwir

2002 The exploration of Musaceae in Irian Jaya (Papua), 11 February-5 March 2002. Montpellier: International Network for the Improvement of Banana and Plantain.

Englberger, L., W. Aalbersberg, P. Ravi, E. Bonnin, G. C. Marks, M. H. Fitzgerald, and J. ELYMORE

2003 Further analyses on Micronesian banana, taro, breadfruit and other foods for provitamin A carotenoids and minerals. Journal of Food Composition and Analysis 16:219-236.

Englberger, L., AND A. Lorens

2004 Pohnpei bananas: A photo collection: Carotenoid-rich varieties. Suva, Fiji: Food Community of Pohnpei and Secretariat of the Pacific Community.

Espino, R.R.C., S. H. Jamaluddin, B. Silayoi, and R. E. Nasution

1991 Musa L. (edible cultivars), in Plant resources of South-East Asia 2: Edible fruits and nuts: 225233, ed. E. W. M. Verheij and R. E. Coronel. Wageningen: Pudoc.

Golson, J.

1977 No room at the top: Agricultural intensification in the New Guinea highlands, in Sunda and Sahul: Prehistoric studies in Southeast Asia, Melanesia and Australia: 601-638, ed. J. Allen, J. Golson, and R. Jones. London, New York, and San Francisco: Academic Press.

Grivet, L., C. Daniels, J. C. Glaszmann, and A. D’Hont

2004 A review of recent molecular genetics evidence for sugarcane evolution and domestication. Ethnobotany Research and Applications 2:9-17.

Horry, J.-P., AND M. JAY

1988 Distribution of anthocyanins in wild and cultivated banana varieties. Phytochemistry 27(8) : 2661-2672.

Jarret, R. L., N. Gawel, A. Whittemore, and S. Sharrock

1992 RFLP-based phylogeny of Musa species in Papua New Guinea. Theoretical and Applied Genetics 84:579-584.

KAGY, V.

1998 The food, socioeconomic and cultural importance of banana in Kanak society in New Caledonia. InfoMusa 7(2):22-24.

Kagy, V., and F. Carreel

2004 Bananas in New Caledonian Kanak society: Their socio-cultural value in relation with their origins. Ethnobotany Research and Applications $2: 29-35$.

KENNEDY, J.

in press Bananas: Towards a revised prehistory, in Ethnobotanist of distant pasts: Essays in honour of Gordon Hillman, ed. A. Fairbairn and E. Weiss. UK: Oxbow.

Kennedy, J., ANd W. Clarke

2004 Cultivated landscapes of the southwest Pacific. RMAP Working Paper 50. Canberra: Resource Management in Asia-Pacific Program, Research School of Pacific and Asian Studies, Australian National University.

KIRCH, P. V.

1994 The wet and the dry: Irrigation and agricultural intensification in Polynesia. Chicago: University of Chicago Press.

1997 The Lapita peoples: Ancestors of the Oceanic world. Oxford: Blackwell.

2000 On the road of the winds: An archaeological history of the Pacific Islands before European contact. Berkeley: University of California Press.

Kirch, P. V., AND R. C. Green

2001 Hawaiki, ancestral Polynesia: An essay in historical anthropology. Cambridge: Cambridge University Press.

Kirch, P. V., D. W. Steadman, V. L. Butler, J. Hather, and M. I. Weisler

1995 Prehistory and human ecology in Eastern Polynesia: Excavations at Tangatatau Rockshelter, Mangaia, Cook Islands. Archaeology in Oceania 30(2): 47-65. 
KIRCH, P. V., AND D. E. YEN

1982 Tikopia: The prehistory and ecology of a Polynesian outlier. B. P. Bishop Museum Bulletin 238.

LEBOT, V.

1999 Biomolecular evidence for plant domestication in Sahul. Genetic Resources and Crop Evolution 46:619-628.

Lebot, V., M. Aradhya, R. Manshardt, and B. Meilleur

1993 Genetic relationships among cultivated bananas and plantains from Asia and the Pacific. Euphytica $67: 163-175$.

Lebot, V., B. Meilleur, and R. Manshardt

1994 Genetic diversity in Eastern Polynesian Eumusa bananas. Pacific Science 48(1) : 16-31.

LejJu, B. J., P. Robertshaw, and D. Taylor

2006 Africa's earliest bananas? Journal of Archaeological Science 33(1): 102-113.

LENTFER, C. J.

2003 Tracing antiquity of banana cultivation in Papua New Guinea: Report on collection of modern reference material from Papua New Guinea in 2002. Unpublished report prepared for the Pacific Biological Foundation, Sydney, Australia.

LentFer, C. J., AND R. C. GReen

2004 Phytoliths and the evidence for banana cultivation at the Lapita Reber-Rakival site on Watom Island, Papua New Guinea, in A Pacific odyssey: Archaeology and anthropology in the Western Pacific. Papers in honour of Jim Specht: 75-88, ed. V. Attenbrow and R. Fullagar. Records of the Australian Museum 29, Sydney: Australian Museum.

LEPOFSKY, D.

2003 The ethnobotany of cultivated plants of the Maohi of the Society Islands. Economic Botany $57(1): 73-92$.

MaCDANiels, L. H.

1947 A study of the Fe' $i$ banana and its distribution with reference to Polynesian migrations. B. P. Bishop Museum Bulletin 190.

Matthews, P. J.

1996 Ethnobotany, and the origins of Broussonetia papyrifera in Polynesia: An essay on tapa prehistory, in Oceanic culture history: Essays in honour of Roger Green: 117-132, ed. J. M. Davidson, G. Irwin, B. F. Leach, A. Pawley, and D. Brown. New Zealand Journal of Archaeology Special Publication. Dunedin: New Zealand Archaeological Association.

Mbida, C. M., W. Van Neer, H. Doutrelepont, and L. Vrydaghs

2000 Evidence for banana cultivation and animal husbandry during the first millennium BC in the forest of southern Cameroon. Journal of Archaeological Science 27:151-162.

Mbida, C. M., H. Doutrelepont, L. Vrydaghs, R. L. Swennen, R. J. Swennen, H. Beeckman,

E. De Langhe, and P. De Maret

2001 First archaeological evidence of banana cultivation in central Africa during the third millennium before present. Vegetation History and Archaeobotany 10:1-6.

McClatchey, W., R. Thaman, and S. Vodonaivalu

2000 A preliminary checklist of the flora of Rotuma with Rotuman names. Pacific Science 54(4) : 345-363.

Merrill, E. D.

1954 The botany of Cook's voyages and its unexpected significance in relation to anthropology, biogeography and history. Waltham, MA: Chronica Botanica.

Nasution, R. E.

1991 A taxonomic study of the species Musa acuminata Colla with its intraspecific taxa in Indonesia. Memoirs, Tokyo: Tokyo University of Agriculture.

1993 Rediscovery of two wild seeded bananas of Indonesia. InfoMusa 2(2):16-18.

Noyer, J.-L., S. Causse, K. Tomekpé, A. Bouet, and F.-C. Baurens

2005 A new image of plantain diversity assessed by SSR, AFLP and MSAP markers. Genetica 124:61-69.

Ploetz, R. C., A. K. Kepler, J. Daniells, and S. C. Nelson

2007 Banana and plantain - an overview with emphasis on Pacific island cultivars, ver. 1, in Species profiles for Pacific Island agroforestry: 1-27, ed. C. R. Elevitch. Permanent Agriculture Resources (PAR), Hōlualoa, Hawai'i. 〈http://www.traditionaltree.org〉. 
Pollefeys, P., S. Sharrock, and E. Arnaud

2004 Preliminary analysis of the literature on the distribution of wild Musa species using MGIS and DIVA-GIS. Montpellier: International Network for the Improvement of Banana and Plantain. Rome: International Plant Genetic Resources Institute.

Purseglove, J. W.

1975 Tropical crops: Monocotyledons. 2nd impression. New York: Halsted Press.

Raboin, L.-M., F. Carreel, J.-L. Noyer, F.-C. Baurens, J.-P. Horry, F. Bakry, H. Tézenas du Montcel, J. Ganry, C. Lanaud, and P. Lagoda

2005 Diploid ancestors of triploid export banana cultivars: Molecular identification of $2 \mathrm{n}$ restitution gamete donors and $n$ gamete donors. Molecular Breeding 16:333-341.

Ross, $M$.

1996 Reconstructing food plant terms and associated terminologies in Proto Oceanic, in Oceanic studies: Proceedings of the First International Conference on Oceanic linguistics: 163-221, ed. J. Lynch and F. Pat. Pacific Linguistics C-133. Canberra: Department of Linguistics, Research School of Pacific and Asian Studies, Australian National University.

SHARROCK, S

1990 Collecting Musa in Papua New Guinea, in Identification of genetic diversity in the genus Musa: Proceedings of an international workshop held at Los Baños, Philippines, 5-10 September 1988: 140-157, ed. R. L. Jarret. Montpellier: International Network for the Improvement of Banana and Plantain.

1995 Collecting the Musa gene pool in Papua New Guinea, in Collecting plant genetic diversity, the technical guidelines: 647-658, ed. L. Guarino, V. R. Rao, and R. Reid. Rome: CAB International, International Plant Genetic Resources Institute.

2001 Diversity in the genus Musa. Focus on Australimusa. Focus Paper 1, INIBAP Annual Report 2000. Montpellier: International Network for the Improvement of Banana and Plantain.

Simmonds, N. W.

1954 Notes on banana varieties in Hawaii. Pacific Science $8: 226-229$.

1956 Botanical results of the banana collecting expedition, 1954-55. Kew Bulletin 11:463-489.

1959 Bananas. London: Longmans, Green and Co.

1962 The evolution of the bananas. London: Longmans, Green and Co.

Simmonds, N. W., AND K. SHePherd

1955 The taxonomy and origins of the cultivated bananas. Journal of the Linnaean Society (Botany) $55: 302-312$.

VALMAYOR, R. V.

2001 Classification and characterization of Musa exotica, M. alinsanaya and $M$. acuminata ssp. errans. InfoMusa 10(2):35-39.

VRydaghs, L., AND E. De Langhe

2003 Phytoliths: An opportunity to rewrite history. Focus Paper, in Annual Report 2002, 1417. Montpellier: International Network for the Improvement of Banana and Plantain.

WEISLER, M. I.

1997 Prehistoric long-distance interaction at the margins of Oceania, in Prehistoric long-distance interaction in Oceania: An interdisciplinary approach: 149-172, ed. M. I. Weisler. NZAA Monograph 21. Auckland: New Zealand Archaeological Association.

WILSON, S. M.

1985 Phytolith analysis at Kuk, an early agricultural site in Papua New Guinea. Archaeology in Oceania 20:90-97.

Wong, C., R. Kiew, J. P. Loh, L. H. Gan, O. Set, S. K. Lee, S. Lum, and Y. Y. Gan

2001 Genetic diversity of the wild banana Musa acuminata Colla in Malaysia as evidenced by AFLP. Annals of Botany $88: 1017-1025$.

Wong, C., R. Kiew, G. Argent, O. Set, S. K. Lee, and Y. Y. Gan

2002 Assessment of the validity of the sections in Musa (Musaceae) using AFLP. Annals of Botany $90: 231-238$.

YEN, D. E.

1973 The origins of Oceanic agriculture. Archaeology and Physical Anthropology in Occania $8(1): 68-85$.

1974 Arboriculture in the subsistence of Santa Cruz, Solomon Islands. Economic Botany $28: 247-284$. 
1982 The history of cultivated plants, in Melanesia: Beyond diversity: 281-295, ed. R. J. May and H. Nelson. Canberra: Research School of Pacific Studies, Australian National University.

1991 Polynesian cultigens and cultivars: The questions of origin, in Islands, plants and Polynesians; An introduction to Polynesian ethnobotany: 67-95, ed. P. A. Cox and S. A. Banack. Portland, OR: Dioscorides Press.

1993 The origins of subsistence agriculture in Oceania and the potential for future tropical food crops. Economic Botany 47:3-14.

\begin{abstract}
This paper reviews recent genetic evidence for the origins of the traditional cultivated bananas of the Pacific, and shows that they are unexpectedly complex. Current assumption of their prevailing west-to-east spread from Southeast Asia into the Pacific thus needs modification. Although bananas are widely assumed to have been part of the set of crops transported to Polynesia at first settlement, the linguistic evidence on which this is based underestimates the diversity of bananas in the New Guinea region and is suspect. Archaeological evidence of bananas is so far very tenuous. Recent genetic evidence of the parentage of most groups of cultivated bananas shows that the primary step toward edibility occurred in the PhilippinesNew Guinea region. Early movements westward across Island Southeast Asia must have occurred, and the complexity of hybrids makes regionally dispersed development likely. There is no demonstrable link with Taiwan or the adjacent coast of China. There is no evidence that the genetically distinct lineages of bananas found in Polynesia were brought together in the putatively ancestral Lapita crop assemblage of the northern New Guinea region. The complex phylogeny of the cultivated Pacific bananas may thus suggest multiple prehistoric introductions of bananas to Polynesia. If bananas were part of the founding set of crops of Remote Oceania, the question "which bananas?" is currently unanswered. Keywords: Indo-Pacific migration and colonization; banana domestication, taxonomy, and genetics; Pacific plantains, $\mathrm{Fe}^{\mathrm{c} i}$ bananas, New Guinea archaeobotany, banana phytoliths.
\end{abstract}

